\title{
THE CHURCH AND THE ENVIRONMENT: \\ ON BEING DOWN TO EARTH IN A CONSUMERIST ERA ${ }^{1}$
}

\author{
Miranda N Pillay \\ Department of Religion and Theology \\ University of the Western Cape
}

\begin{abstract}
Based on the premise that both anthropocentricism (humans over the environment) and patriarchy (men over women and children) operate as hierarchies to oppress and subjugate 'others', this article makes a connection between patriarchy and prosperity preaching by arguing that in both instances, biblical texts are used to 'sanctify' and sustain hierarchies of power. In order to develop my argument as it relates to hierarchical power, I engage insights gained from Feminist theology. Two case studies are presented as examples from popular current religious/ spiritual movements to illustrate how a hierarchy of power 'presents itself' as 'naturally right'. I then explore the relationship between prosperity preaching and consumerism, and between BRICS ${ }^{2}$ and consumerism, respectively. Finally, an argument is made for the church to take seriously the fact that hierarchies such as patriarchy and anthropocentrism are made 'palatable' by a theology of prosperity - by exploring theologies that will bring Christians 'down to earth'.
\end{abstract}

Keywords: Environment, Consumerism, Power Hierarchies, Feminist Theology, Prosperity Teaching/Preaching

\section{Introduction}

The term 'environment' has many connotations and is often used interchangeably with terms such as 'nature', 'ecology', 'the earth' and 'creation'. However, the meaning of these terms 'has become contested' says Conradie (2003:123). An example is the argument made by ecofeminists that 'ecology' rather than 'environment' is the preferred word because it has 'a more holistic meaning' according to Rakoczy (2009:114). ${ }^{3}$ One can understand this preference, given that 'ecology' is etymologically linked to the Greek metaphor oikos meaning 'house' or 'household (Conradie 2003:124; Warmback 2008:151; Rakoczy 2009:114). The ecofeminist preference for 'ecology' could possibly be made on the basis of the sense of social justice evoked epistemologically by oikos-particularly in terms of the health of the whole household of God. ${ }^{4}$ Furthermore, as pointed out by Conradie (2003:124), this household of God' (oikos) is also linked to 'the whole inhabited world'

\footnotetext{
Paper read at conference on 'The Church and the Environment' held at Baptist University College, Kumasi, Ghana, 26-30 April 2011.

2 BRICS is the acronym for the new economic block with participating countries being Brazil, Russia, India, China and South Africa.

3 In an earlier publication Rakoczy (2004:301) refers to 'holistic' in the same sense.

4 However, there is also an awareness of dualism in the Greco-Roman sense where oikos (household/private) functioned as the opposite to polis (city/public) which impacted on how views on gender were shaped.
} 
(oikoumene). Rakoczy (2009:114) notes that the reason for ecofeminists' choice of the word 'ecology' is based on the idea of "the interdependence of all the elements that are related to the human world".

It is not my intention to argue here for one particular term over another - but rather to account for the reasons why a particular term may be epistemologically more appealing for championing a specific cause. Secondly, it serves to 'situate' the essence of my argument, which is the need to challenge hierarchical relationships.

My (very preliminary) observation that all these often contested terms relating to the 'environment' have a place in discourses relating to environmental concerns, is based on Conradie's explanation that there is a need for a multidisciplinary approach which "understands the logic of our planetary household" (Conradie 2003:125). Conradie reiterates this view and explains that there is a general awareness that, "We need to read the Bible through different lenses; we have to reframe our understanding of the content and significance of the Christian faith..." (Conradie 2011:1-2).To this end, the premise of my argument is that insights gained from ecofeminism - which is based on four core principles, viz. "the interconnections of the oppression of women and that of creation, the need to understand this insidious connection, the expansion of feminist theology to include ecological perspectives, and the conviction that ecological problems cannot be addressed without a feminist perspective"5 (Rakoczy:2009:114) - can be an example of reading the Bible through different lenses. ${ }^{6}$

The point of departure for ecofeminists is that both anthropocentricism (humans over the environment) and patriarchy (men over women and children) operate as hierarchies to oppress and subjugate. ${ }^{7}$ Thus ecofeminism brings together the disciplines of feminism and ecology in a way that exposes the connection between the domination of women by men and the domination of the natural world by human beings. At this juncture, I observe that the Bible - as a primary Christian resource - had been (ab)used to serve, maintain and perpetuate both these hierarchies of oppression in the church and society. The same argument also holds for social hierarchies operative in attitudes, laws and practices of slavery, servitude, racism and homophobia. Thus, the call by the Circle of Concerned African Women Theologians that men and women are to re-read Scripture is a call to retrieve the liberative and transformative potential of the Bible. ${ }^{8}$ This, I believe is firstly because the Bible had also been (and continues to be) used to argue for liberation and transformation against oppressive social practices such as apartheid, slavery etc.; and

5 While feminists have 'taken their cue from black theology' drawing on liberation theologies, they call into question the full range of human relationships and church life (Weidman 1984:2) in relation to every contemporary issue. "Most liberal theologies begin with experience", notes Weidman (1984:3) and for African women theologians it starts by African women voicing (in writing) their journeys of faith - via roads that connect (for example) culture, livelihood, the environment, the church, etc. This thinking is underpinned by the broader methodological shift in feminist theological anthropology, viz. experience as the starting point for theological reflection (Hinsdale 1995:31).

6 Desmond Tutu, in the 'Foreword' to The Earth Story in the New Testament says, "Feminists have forced us to confront the patriarchal orientation of much of the biblical texts. Earth Bible writers are now confronting us with the anthropocentric nature of much of the biblical texts" (2002:vii).

7 Ecofeminists reject the 'kingship' model where human beings dominate and subdue the earth (Hinsdale 1995:30).

8 The primary goal of the Circle is to encourage, mentor and support women to write and publish - through engaging and being in dialogue with "all other theologians, women and men, in Africa and beyond" (Kanyoro 2002:19). African women theologians also continue to challenge the traditional male, individualistic, hierarchical approach to biblical interpretation (Pillay 2005:446). 
secondly, for liberation to come to effect and be effective, both the oppressor and the oppressed have to 'see' the wrongness, uselessness, or in Christian terms, the 'sinfulness' of the oppression. Of course, the converse is also true: For oppression to be effective, the oppressor and the oppressed have to 'buy into' it as being right or useful- or sanctified in Christian terms! Thus, in order for the church to shape (and sharpen) unique Christian responses to the (already manifested and continuously emerging) ecological crises, it might have to release 'holiness' from the shackles of the power of hierarchy which has served to exploit Christian values such as love, care, and stewardship. For example, the Christian value inherent in 'stewardship' is 'to care for' (Vorsorge) ${ }^{9}$ but it is often subverted to mean 'ruling over' or to 'exercise power over', which serve to uphold structures of hierarchy. ${ }^{10}$

In order to develop my argument as it relates to hierarchical power, I propose to first adjust our reading lenses with some insights from a Feminist theological perspective (section one). This will be followed up with two case studies as examples from popular current religious/ spiritual movements to illustrate how hierarchy of power 'presents itself' as 'naturally right' (section two). In sections three and four I will explore the relationship between prosperity teaching and consumerism; and then between BRICS and consumerism, respectively. In section five I explore an alternative to 'prosperity theology' as a response to consumerism which is (and already has been) exploiting the earth. Finally, I make some concluding remarks.

\section{Oppression: Power and Hierarchy}

My reference to oppression relates firstly, to the theoretical framework espoused by Iris Marion Young (1990) ${ }^{11}$ and secondly, it relates to concepts of external oppression and internalised oppression as explained by Louise Kretzschmar (1998). Young argues that oppression does not only mean the "exercising of tyranny by a ruling group" (1990:40). She explains that 'oppression' also refers to "the vast and deep injustices people suffer as a consequence of often unconscious assumptions and reactions of well-meaning people in ordinary interactions, media and cultural stereotypes, and structural features of bureaucratic hierarchies and market mechanisms - in short, the normal processes of everyday life" (1990:41). Oppression is often the result of understanding difference in terms of essential natures that determine what group members deserve or are capable of (Young 1990:47). ${ }^{12}$ There is no one essential definition of oppression, says Young who then goes on to explain that oppression may be experienced as exploitation, marginalization, powerlessness, cultural imperialism and violence. ${ }^{13}$

9 'Vorsorge' according to Huber (1993:582) is "prospective care for a future of a shared realm of living together" and must be differentiated from Fürsorge (instinctive care). See Pillay (2003a:112).

10 Hinsdale (1995:30) points to the argument made by ecofeminists that, while the idea of 'stewardship' calls for human beings to be caretakers the idea also perpetuates the structure of hierarchical dualism and is blind "to the fact that human beings are also dependent upon the earth".

11 Also see Sporre (2009:262).

12 Two examples come to mind here. Firstly, the oppression suffered by sero-positive persons due to the view held by some people that HIV-positive adults deserve to suffer because they 'bring illness upon themselves' and the stigmatization of HIV-positive women who have children while HIV-positive children, particularly AIDS orphans are viewed as 'innocent children' who cannot 'help' that they have the disease. Secondly, some people still hold the view that a woman should be denied the right to have an abortion as she deserves to suffer as 'punishment for sin' (See Pillay 2006:80). This Augustinian approach to suffering views human suffering as a result of human sin (Conradie 2005:418).

13 Young identifies this as the 'five faces of oppression' (Young 1990:39-65). 
South African feminist theologian Louise Kretzschmar gives a succinct overview of how gender oppression is understood in terms of 'external oppression' and 'internalised' oppression. ${ }^{14}$ External oppression manifests itself in two ways: 'exclusion', which prevents women access to areas of influence such as politics, church government ${ }^{15}$ and the economy and aims to restrict women to service in the context of home and family and secondly, 'androcentrism' which is the "habit of thinking about the world, ourselves, and all that is in the world from the male perspective... Androcentrism drowns or silences women's voices and perceptions ..." (Kretzschmar 1998:173; Pillay 2008:211-212). ${ }^{16}$

Internalised oppression says Kretzschmar (1998:173)

...occurs when the oppressed accept or internalise the negative perceptions that those in power have of them. The powerful develop the systems and define the roles that they wish others to play in these systems.

The oppressed allow themselves to be conquered when they accept the inferior (often subserviant) roles ascribed to them as being 'good for them', appropriate and proper. The result is that in the case of patriarchy many women would defend a 'system' and in some cases accept the abuse (physical, sexual, emotional, etc.) of patriarchal oppression and violence. People who defend differentiation of social roles, talents, capabilities, etc. believe (explicitly or implicitly) that a social structure based on sexual differentiation can be justified by 'nature' (Nagl-Docekal 2004:2; Holmes 1998:106-107). ${ }^{17}$ Thus, it is 'in womens' nature' to be irrational, weak and 'in need of' while it is 'in men's nature' to be rational and strong in order to provide for and protect 'their' women. ${ }^{18}$ This seems innocent enough, says Sarojini Nadar (2009:22) because the idea of men taking responsibility is 'hardly unpalatable'. ${ }^{19}$ She argues that this 'palatable' patriarchy is what sustains male headship and the submission of women to men in most religions and cultures. ${ }^{20}$ Sometimes leaders of churches challenge this hierarchical attitude and behaviour at 'fitting occasions'. For example, in 2005 the then Archbishop of Cape Town, Rt Revd Ndungane in his charge to Synod called the Anglican Church to "repent of the historic patriarchy of our faith":

We must repent of the historic patriarchy of our faith which so often colludes with discriminatory attitudes in our cultures. We must expose and oppose gender violence and all forms of inequality in our midst. We must build girls' and women's self esteem,

14 I have used these categories to explore how HIV-positive individuals experience 'stigma' as oppression (See Pillay 2008:209-217).

15 See the following articles where I have dealt with issues of gender injustice in the church: Women in the Church: Solidarity in suffering in the context of HIV/AIDS (Pillay 2003b:142-163); Women in the Church: Towards Developing Community in the Context of HIV and AIDS (Pillay 2009a: 95-114). Through the Eyes of a Mother: Re-Reading Luke's Mary as a Resource for Gender Equality in the 21 ${ }^{\text {st }}$ Century? (Pillay2009b:219232).

16 Being silent (or silenced) does not mean that women (or other marginalized groups) have nothing important to say.

17 See Holmes (1998:94-110) for an overview and evaluation of morality based on nature.

18 The idea that "men are superior to women simply because they are men" is referred to as 'sexism' (See Ackermann 2003:30). Ruether explains that 'sexism' is understood to be both violence and violation to women's bodily integrity, humanity and capacity to full selfhood - which in itself is a distortion of male humanity (Ruether 1993:242; cf. Pillay 2009b:96).

19 In the same way, clearing forests to make way for economic development projects seems plausible and palatable to 'poor, developing' nations.

20 In a public response to the woman who dared challenge the culturally endorsed sexual power of Jacob Zuma, pro-Zuma supporters chanted 'Burn the bitch!' outside the Johannesburg High Court in the rape trial of Jacob Zuma (Judge 2009:13). 
assertiveness and interpersonal and leadership skills. We must declare and demonstrate the dignity, respect and honour of all, regardless of gender (Daily News, 7 July 2005:2).

In my opinion, it is the sanctification of male headship (of our faith) that almost compels women and men to defend patriarchal hierarchy. Thus, I agree with Nadar who warns that Angus Buchan, founder of the Mighty Men Conference, "sets up a very palatable patriarchy", first by calling men to claim their "rightful position in the home as prophets, priests and kings" and then by admonishing them to be responsible (2009:23). I believe Buchan is subverting the pressing need for reflection on the values of 'positive masculinities ${ }^{, 21}$ by appealing to what he perceives to be the natural, inherent, sanctified and 'Godgiven' superior position of men over women. This is patriarchal masculinity which teaches men that their sense of self and identity, their reasons for being, resides in their capacity to dominate others (Hooks 2000:70) ${ }^{22}$ Hooks says that many men blame the fact that more women are entering the formal employment sector for being unemployed and for their loss of the stable identity that patriarchy gives them (2000:53).

Retrieving men's privileged position in the hierarchy of patriarchy might well be what the Mighty Men Movement is all about since it 'preaches' that men have lost sight of 'God's will' for them which results in them becoming weak and irresponsible. ${ }^{23}$ The 'movement' becomes 'the way' back to God's plan for God's people and husbands are encouraged to reclaim their God-given power as heads of household by taking care of wife and family. This, Buchan claims will be in accordance with the Pauline directive (although Buchan incorrectly puts these words in the mouth of Jesus $)^{24}$ that 'husbands must love their wives'. This in turn will ensure that wives give effect to the (Pauline/Deutro-Pauline) directive 'to respect and obey'. It appears that both men and women find hope in this 'gospel' message as Buchan's wife, Jill endorses male headship when she says:

The church of God needs men. They need fathers, they need everything set back in order [restored to order?] because the church is still full of homes that are still struggling with headship and God says he's going to sort out the church first. He has to re-instate the men, and when he does that, the women will be very happy. ${ }^{25}$

It appears that the wives of the 'mighty men' are pleased that their husbands will 'be changed' because they want their husbands to be protector and provider, while husbands are encouraged by the promise that their sense of identity as 'head' will be 'restored'. Sounds like a win-win situation. "What is so bad about patriarchy? It works!"26 I will not

21 Domoka Lucinda Manda (2009:23-36) draws our attention to research emerging on how ethical theories and religious principles shape (or should shape) and 'direct men' which has given body to men's movements such as 'Men as Partners' (South Africa), 'Men's Forum on Gender' (Zimbabwe) and 'The Movement of Men against AIDS' (Kenya).

22 Closer to home, this idea was illustrated when (in 2009) I tuned into a local (Cape Town) radio station during a programme on the morning of the start of "Sixteen days of activism against violence against women and children" campaign. The announcer took calls from a number of listeners - many of whom expressed their concern at the increase in the rate of violence against women by their male partners, despite new laws relating to domestic violence. Other views were also expressed as one woman caller said, "Men have no choice because women 'don't know their place"” while another woman caller said, "Nowadays the woman want to defy the man... the Bible says, the wife must obey her husband".

23 This might also be a result of what Nadar (2009:250) refers to as 'the crisis for Afrikaner men' in the face of the nature of Afrikaner hegemonic masculinity being challenged in post-apartheid South Africa.

24 As Nadar (2009:23) also points out.

25 Nadar (2009:24) referring to an interview on Carte Blanche (a South African investigative television programme).

26 This is a statement/question put to me during the presentation of my paper "Religion, Gender and AIDS: What 
enter into a debate on the perceived 'goodness' of patriarchal rule other than say that 'it works' because women and men (and children) accept it as 'the natural order of things' but more so because it is believed to be God's will according to God's word. This is what makes patriarchy a palatable, holy hierarchy.

\section{Another Holy Hierarchy: Rich over Poor}

Let's teach people how to work and save and put their money to work in income-generating assets. Let's teach them to create wealth and get out of the poverty mindset. It is really possible. That's what Releasing Kings is all about. ${ }^{27}$

The above quotation is from an article "It's easy to create Wealth" which I came across while reading up on the Mighty Men Conferences - both of which were posted on a website (www.crossconnections.net/mighty-men-conference-2010). ${ }^{28}$ Written by John Garfield, coauthor of the book "Releasing Kings for Ministry in the Marketplace" the article was submitted to the cross connections website on 11 November 2010 by an organization 'Serve the Servants' - all these names that suggest 'good intentions'. Garfield says that people who are poor do not "believe they can create wealth [and] have lost hope..." Under a sub-heading entitled 'The Promise' he argues that:

God has given every believer the ability to have life, and life more abundantly. He gives us talents and opportunities to exploit. Our stewardship of those opportunities and ideas is a key ingredient of faith that creates wealth. I have to believe that wealth is a possibility for me. If I know that learning to multiply money is part of God's plan for me, I will watch for the opportunities (Garfield, 2010).

This argument is then buttressed with texts from 2 Corinthians 8:9 and 2 Corinthians 9:1011 with further explication that "we own the responsibility to create wealth before God". According to this article misguided giving reinforces poverty and results in "too much money in the hands of people [who are] not mature enough to multiply it". 'Misguided giving' according to Garfield is "giving money to people in a lifestyle of poverty (Garfield, 2010)". Here, Matthew 25:28-30 is used as proof text to explain that God effectively transfers wealth from the poor to the wealthy: "God himself transfers wealth from those who lose it to those who steward it" (Garfield, 2010). Garfield also warns that often our benevolent redistribution of wealth works against the plan of God. He further argues that helping those in poverty requires an adjustment of "our definition of discipleship to include wealth creation" (Garfield, 2010).

The following reflection on both case studies -Mighty Men Conference and Releasing Kings for Ministry in the Marketplace - will connect the title of my article: "The Church and the Environment: on being down to earth" with the next section which identifies consumerism as an urgent environmental challenge (and I am tempted to refer to the challenge as 'eco-environmental'). I observe that in both instances 'stewardship' could mean 'selfenrichment' or 'self-fulfilment' which requires one to 'take control'. Secondly, the 'benefit' is prosperity which is a promise to be claimed only by those followers of Jesus who obey God's word (Scripture). Furthermore, both Buchan and Garfield believe that they are responding to God's call to bring God's people back to God's ways. For Buchan: Wives

more can be said?" at a conference in Stellenbosch, 6 October 2010.

27 See www.releasing-kings.com.

28 To view Garfield's article in its original format and typesetting see www.identitynetwork.org/apps/articles/default.asp?articleid=70355\&columned=noref. 
must obey their husbands - and it is the husband's God-given responsibility (to 'love' his wife) that will to see it that his wife is obedient to God's command to obey. For Garfield: Those who are already experiencing God's promise of wealth must show others 'the way' to wealth. In my view, Garfield's teaching subverts (and misrepresents) the Christian values of 'stewardship' and discipleship and that it serves to perpetuate a 'palatable' hierarchy of rich over poor. What is wrong with being rich in a context where what one possesses is seen as a sign of God's blessing upon a life lived in faith?

\section{Prosperity Teaching and Consumerism}

Prosperity teaching is a reality and its influence amongst contemporary evangelical Christians should not be underestimated, says Trinity Theological College professor, Roland Chia (2011:6). ${ }^{29}$ While prosperity teaching has its roots in charismatic Protestant Christianity and is readily associated with preachers such as Kenneth Hagin, Kenneth and Gloria Copeland, Bennie Hinn and Joel Osteen, it is not confined to affluent countries like America. A survey done by the Pew Research Centre on Christians in Africa reveals that nine out of ten Christians believed that "God would grant prosperity to all believers who have enough faith" (Chia 2011:6). ${ }^{30}$ The emphasis on faith makes prosperity teaching plausible amongst Christians and sanctifies wealth over poverty. ${ }^{31} \mathrm{~A}$ lack of faith is cited as the reason why Christians are not getting the returns allegedly promised in the Bible. Thus, to live in poverty is to violate the will of God.

Chia (2011:6-7) argues that the 'chief problem' with prosperity teaching has to do with the 'interpretation and application of Scripture'. Giving the impression that their doctrine is firmly grounded in Scripture, prosperity teachers usually buttress their doctrine with numerous proof texts - plucked out of their literary and cultural contexts. This, together with an emphasis on faith makes prosperity teaching a plausible theology. My earlier reference to texts quoted by Buchan and Garfield confirms this observation. Another problem is that by emphasising material wealth, prosperity theology endorses materialism and legitimises greed. This is not surprising since prosperity theology lends itself to the prevailing consumerist culture. Moreover, in the case studies discussed earlier, it is clear that both prosperity movement leaders (Buchan and Garfield) have something to sell and therefore they are out to convince their clientele that their product is genuine. Thus, they make their 'theology' marketable by quoting Biblical texts (out of context).

In the context of 'emerging economies' wealth creation and prosperity are appealing concepts in African societies. Given South Africa's focus on 'growing the economy'and 'job creation' it is not surprising that the South African government has 'bought into' the idea of prosperity which its BRICS membership appears to hold.

\section{BRICS: A Catalyst for increased Consumerism?}

The world market compels the Third World to abandon their own subsistence economy and plant monocultures for the market's use (Conradie 2000:63).

29 In a feature article published in St Andrew's Cathedral (Singapore) magazine The Courier.

30 In the same year a survey by Time Magazine revealed that $61 \%$ of the Christians in America surveyed believed that God wants people to be prosperous, although only $17 \%$ directly identified themselves with prosperity theology (Chia 2011:6).

31 This belief is reflected in the names of Ghanaian businesses. It was with fascination that I (and two UWC colleagues) noted the names of some businesses in Kumasi, Ghana, vz. Holy Head Beauty Salon, King of Kings Razor Wire, Jesus the Redeemer Printers, etc. 
In the above quotation, Conradie uses Moltmann (1996) as a source of reference. Meanwhile, the world market landscape has changed dramatically with China capturing a large share of the world market. ${ }^{32}$ It is not surprising that almost everything is "made in China'. ${ }^{33}$ The thirty years of market reforms have brought immense changes to China's place in the world economy. It is no longer only the "unsustainable level of consumption of industrialised first world countries" which raises environmental concerns but also the 'reckless pursuit of high growth' of China which is the cause of huge ecological imbalances. ${ }^{34}$ With the massive growth in energy demand and reliance on fossil fuels and coal, China has become the world's largest emitter of greenhouse gasses, says Gregory Albo (2008).

China's advancing economic development is indicative of the shift in global economic power "away from the developed G7 economies towards the developing world" (www.wikipedia.org/wiki/BRIC, Kowitt, B 2009). Brazil, India and Russia are said to be at a similar stage of newly advanced economic development together formed and economic alliance adopting the acronym 'BRIC' (Brazil, Russia, India and China). ${ }^{35}$ The Goldman Sachs global economics team predicted in 2003 that "China and India respectively will become the dominant global suppliers of manufactured goods and services" while Brazil and Russia will become dominant as suppliers of raw materials. The 2007 follow-up report on BRIC compiled by Tushar Poddar and Eva Yi note significant areas of growth and expansion in India - which will lead to "the prosperity of the growing middleclass"(Podder, T \& Yi, E 2007).

On 24 December 2010, South Africa was formally admitted as a 'BRIC' nation, resulting in the five-letter acronym, BRICS. Some economists have expressed their surprise since South Africa's inclusion makes very little commercial sense. However, South African emerging market expert, Martyn Davies argues that South Africa's inclusion in BRICS is an astute political move given "China's attempts to establish a foothold in Africa" (Conway-Smith, E 2011).Moreover, South Africa's inclusion "may translate to greater South African support for China in global fora"(Conway-Smith, E 2011). Furthermore, geopolitically, African credentials are important for the credibility of this new economic block (Smith, JA 2011).

South African President Jacob Zuma attended the BRICS Summit held in Sanya, China (14-15 April 2011) as a newcomer. Reiterating that being included in BRICS is a privilege for South Africa, President Zuma said that it (South Africa) had 'unique attributes' which would help boost its fellow BRICS members. In his address Zuma also said that, "It is just natural that our partners will look at South Africa as a springboard into the region and for us to provide guidance and development opportunities" and "as a major player in Africa's financial markets, minerals, industrial and services infrastructure and electrical generation, South Africa had much to offer" BRICS partners (www.afriqueavenir.org/en/2011/04/14; www.southafrica.info/global/brics/).

South Africa is seen as "gateway for BRIC trade into resource-rich nations of Africa", reports Robert Hsu, editor of China Strategy on 23 April 2011. Hsu notes that South

\footnotetext{
See Star Tribune article "China's share of world market rising" (The Economist 2011).

And Chinese capital is actively engaged in an acquisition surge around the world (The Economist 2011).

34 There are also many social imbalances in China's capital growth processes, says Albo (2008). The conditions for the estimated 350million Chinese waged workers remain difficult.

35 Each of the BRIC partners has vested interests in the alliance but my discussion will centre on the dynamics between China and (South) Africa.
} 
Africa's inclusion is significant because it has "transformed the group into a truly global entity" and he also mentions the fact that "South Africa is largely seen as a gateway for BRIC trade and investment into the resource-rich nations of Africa" (Hsu 2011).

Many questions come to mind regarding the socio-political and socio-economic impact of South Africa's alliance with BRICS: Is this yet another 'scramble for Africa' guised as a palatable 'win-win' concept? Is this the beginning of a new palatable hierarchy of economic control and exploitation? If China's existing pollution problem is of global environmental concern, what could be the environmental impact of this newly forged relationship with South Africa - on Africa as a whole?

Already the Business Day of 23 April 2011 also carries a report that the Chinese are "to send high level delegation to explore opportunities in Africa's energy sector" (Latham 2011), and that China is targeting "new power generation methods such as solar and hydroelectrical schemes for growth" (Latham 2011) - which certainly makes it a plausible expedition. Besides, the relationship dynamics is being forged as China Development Bank has also recently announced that it is to channel \$1,5-billion to China's BRICS partners to fund infrastructure projects (Latham 2011). Is BRICS Africa's new hope? Or is Africa BRIC's new hope? Is an increase in manufacturing goods the answer to Africa's hunger and poverty; or is it another opportunity for instant gratification and 'get rich quick' opportunities for a selected few? Will the ordinary (South) African and Chinese continue to scramble for the economic crumbs at street corners - begging (and haggling) passersby to purchase yet another plastic gadget or counterfeit merchandise, albeit in the name of entrepreneurship? Is the BRICS economic block another form of external oppression that will cause further 'forced pauperization' and lead to internalized oppression where the poor regard themselves as 'handicapped capitalists'? ${ }^{36}$ These are only some of the crucial questions that cannot be explored in this article. By raising them here though, I hope that, besides academia, these issues will also find a place on the agendas of churches, faith-based organizations, other civic and non-governmental organizations, various governmental fora, etc.

In this regard it is encouraging to note the report in African Christian Pulse (2011:7-8):

All Africa Conference of Churches organised a 2-day Networking consultation with African Civil Society during which the participants observed that there is a need for civil society organizations and churches to enter into a debate about the exploitation of African resources. Participants also resolved (amongst other things) that the time is ripe for Africa to ask the hard questions about the role of aid in its development.

My argument thus far has been: Based on the premise that the church needs to release 'holiness' from the shackles of the power of hierarchy if it wants to shape a (uniquely) Christian response to the (already manifested and continuously emerging) ecological crises, I have argued thus far:

- that a feminist perspective is imperative;

- that the 'theological' principles, as espoused by proponents of popular current religious/ spiritual movements, relate to prosperity preaching which encourages consumerism and 'sanctifies' the power of hierarchy based on proof texts quoted out of context;

- That there are socio-politico-economic and ecological challenges inherent in South Africa's inclusion in BRICS which call for critical ethical and theological reflection on the 'promise' of development in Africa as an 'emerging economy' and the socio-

36 See Dorothee Soelle's “On Earth as in Heaven” (1993). 
environmental concerns which the ever increasing demand of manufactured goods hold for the African continent.

In the light of this argument, the need for alternatives to 'prosperity theology' is obvious. In challenging financial prosperity as a 'God-given' right of the faithful believer or patriarchy as a God-given male privilege or the human being's God-given right to subdue the earth, we (the church) have to turn to Jesus of Nazareth - the one who came down to earth.

\section{The Church: On being down to Earth}

To be 'down to earth' could (amongst other things) mean: not to be arrogant, conceited, patronizing, superior, high-and-mighty. To say someone is a 'down to earth person' is usually to pay the person a compliment. It is used in a positive sense, as one who is 'down to earth' generally reflects a 'good' character trait. But is this really (still) the case? How could this be when, to be 'down to earth', is to be alien in a world where being higher, up, above, on top is the measure of success? How is it possible to desire 'being down to earth' in a context where to have 'more' and 'bigger' is the hallmark of material prosperity in a consumerist society - believed to be a sign of God's blessing for many Christians? ${ }^{37}$ This is a daunting task especially in the light of 'newly liberated voices' who expect, want and demand 'equality' based on norms of a consumer society maintained by affluence and wealth. This is even more difficult when such norms are sanctified with 'holy' presuppositions and 'propped up' by proof texts. In this way biblical texts are (ab)used to perpetuate the materialist assumption that poverty has to be avoided at all cost.

The enormity and complexity of the issue could easily lead to indifference, hopelessness, despair or inertia. But Christians are a people of hope. And that hope is Jesus Christ whom we celebrate in the Eucharist- the origins of which do not lie in success or triumph, says Denise Ackermann (2005:394) who also reminds us that "Jesus Christ was betrayed and handed over to the powers of the world". It is during the Eucharist when individuals constitute the 'church as worshipping community' that all those who are 'partakers' become aware of their interdependence with one another. In essence, by their participation in the Eucharist, the many (rich and poor; men and women) become one (on earth) in Christ, who is in Heaven. To me, this relationality is what Dorothee Soelle refers to as a prerequisite for 'hope' when she says, "I need to ground heaven on earth" in the introduction to her book On Earth as in Heaven (1993). The title, Soelle reminds us, is a prayer:

It claims our hope for this world and for ourselves: there will be a time when God's will or dream will be done not only in God's realm among cherubim and seraphim but on earth amongst principalities and powers as well. To pray does not mean to ask someone else to fulfill, instead of us, what we cannot bring forward. It means to co-operate with God, it asks that we may be empowered and commissioned. We may say God has a dream about us humans; in prayer we end letting God dream alone, we participate in God's dream, we join (1993:ix).

37 This is an example of what Conradie refers to as 'commodification' and is an indication that 'almost anything can become commodified' (2010:90-94). He also notes how the relentless drive to commodify has turned public places into advertisement spaces. For example, during a recent visit to Ghana (where colleagues and I attended a conference on 'The Church and the Environment' we noticed the many houses that are painted luminous green to advertise a cell phone company or yellow to advertise a popular brand of latex/foam. Also see footnote 32 . 
In a prayer request for Earth Day ${ }^{38}$ this year, Colin Moodaley (environmental co-ordinator of the Diocese of Saldanha Bay) ( $^{39}$ asked "fellow clergy and people of God to dedicate 5-10 minutes "to honour Earth Day on Good Friday". ${ }^{40}$ In his request to 'mark Earth day' Moodaley asked that churches (congregations/parishes) include some environmental prayers in the liturgy planned for the Good Friday worship service as "it is a way of reclaiming the theology that the earth is 'very good' and is holy".

A World Council of Churches Study Document describes worship as "a special moment for celebration - an attempt to place daily life on the stage". It states that:

Worship can help churches to remove the barriers we create in the everyday life of our human communities by opening our eyes, our ears and all our senses to the extraordinary significance of the 'ordinary' experiences and to ways of expressing God's presence amidst the people and creation (1997:78-79).

While Christian worship provides creative opportunities for affirming how 'we see' God, ourselves, others and the environment, in which and with which we interact, it also provides unique opportunities to help us "look in the right direction" (Smit 1997:272). ${ }^{41}$ It is within the 'space' created during worship that the opportunity exists for the changing of the hearts and minds of Christians. As Elna Mouton puts it:

The worship service as the central point of all ecclesial activities and experiences, is essentially rhetorical in nature. It is the primary context where believers are continuously constituted and affirmed as a community of believers, as the 'household of God'. It is the primary location where a collective identity is assigned to them, where they learn to know who they are and 'Whose' they are. This is where they learn to dream about God's future which has already become a reality in Christ, and from where they are being sent out to care for one another and the world. From here God's household (as a social, communicative, domestic, economic entity) moves into society to proclaim God's presence in the liturgy of everyday life (2003:16).

Christian worship has ethical implications for public life because worshippers learn to see the world in a certain way, says Smit (1997:261). This is why Smit also warns that Christian worship is an ambivalent phenomenon - while it has the potential to change the way we see things, it can (and has been) used to avoid what we should see (1997:272).

\section{Concluding Remarks}

It is important that the 'church' in all its forms ${ }^{42}$ respond to the ecological crises. The examples that I have referred to is an indication that this is happening: I have shown how the 'institutional church' (Diocese of Saldanha Bay), having appointed a Diocesan

38 This year (2011) Earth Day was celebrated on Friday 22 April - which was also Good Friday.

39 Colin Moodaley is an ordained minister in the Diocese of Saldanha Bay, (one of three Dioceses of The Anglican Church of Southern Africa in the Western Cape) and also a lecturer at the University of the Western Cape.

40 The request was sent via e-mail to parishes in the Diocese and included a prayer from the National Council of Churches (see http://www.webofcreation.org/Worship/liturgy/prayers.htm\#earthday).

41 Smit (1997:272) warns, though, that Christian worship is an ambivalent phenomenon - while it has the potential to change the way we see things, it can be (and has been) used to avoid what we should see and thus it can entrench the status quo.

42 By this I mean what is generally referred to as the 'six manifestations of the church', viz. the church as worshipping community (Sunday worship service); The local church (parish); Denomination (Institution viz. Synod); Ecumenical church (e.g. WCC); Volunteer organizations (e.g. Anglican AIDS and Healthcare Trust); Individual Christians (Smit 1996:119-129; Pillay 2005:442). 
environmental co-ordinator has reminded 'local congregations' to mark Earth Day by including an "environmental prayer" (from the National Council of Churches) and a suitable 'hymn or two' during the Good Friday Worship service. For these very important initiatives to move beyond paying 'lip-service' or 'paper-service' which puts on record that the church 'doing something' there has to be some 'follow through' and follow up. Moreover, for these initiatives to move beyond an annual event of saying a prayer, awareness and advocacy have to be sustained through a meaningful and reflective theology by the church in all its manifestations (of being church). By referring to two case studies, ${ }^{43}$ I have suggested that the church reflect on its theology of hierarchy - particularly those 'palatable' hierarchies which are sanctified by oppressive readings of biblical texts.

I think it is important that the church (particularly as institution) takes note of the teachings of movements such as the Mighty $\mathrm{Men}^{44}$ and Releasing Kings for Ministry. While it (the church) cannot prohibit its members from attending gatherings of these movements or prevent its members from 'buying into' the theology that these movements propagate, it (the church) should firstly discern its own role in promoting these movements when advertising it in church newsletters/ bulletins and announcements during worship services. Secondly, the church should offer its members an alternative theology $y^{45}$ - not one rooted in hierarchy of patriarchy or prosperity or anthropocentrism, but a theology embedded in the relationality exhibited in the care and love of God who came down to earth.

'Relational' means standing in relation to (Soelle 1993:9). We cannot speak about the promise of economic development in Africa without speaking about increased consumerism and the promise of profit it holds for those who invest in Africa. This is why the church in all its manifestations should 'hear' the prophetic call for the need for civil society organizations and churches to enter into a debate about the exploitation of African resources. Now is the time for Africa to ask the hard questions about the role of aid which, in the name of development and prosperity, makes exploiting the earth's resources palatable.

\section{BIBLIOGRAPHY}

Ackermann, DM 2003. After the Locusts: letters from the landscape of faith. Grand Rapids, Michigan: William B Eerdmans.

Ackermann, DM 2005. Engaging Stigma: An Embodied Theological Response to HIV and Aids. Scriptura 89:385-395.

The African Christian Pulse. A Bulletin of the All Africa Conference of Churches, Jan-Feb 2011:7-8.

\footnotetext{
43 Although these Christian movements (Mighty Men Conference and Releasing Kings for Ministry) do not fall neatly into the 'general categories' of understanding 'church', it could be argued that these movements represent the church as volunteer organization. However, Buchan himself claims that his organization (Mighty Men Conference) is not 'the church' but a way and means to make God's way known (to men).

44 And other like-minded movements like the Promise Keepers in North America (Nadar 2009:23; http://www.ministrywatch.com/profile/promise-keepers.aspx).

45 Especially since these movements appear to 'undo' the strides made by the church in terms of social justice issues - particularly in the areas relating discrimination, domination, and/or subjugation based on tradition and scripture.
} 
Conradie, EM 2011. "The Church and the Environment. Seven Stations towards the Sanctification of the whole Earth. Conference at the Baptist University College, Kumasi, Ghana-26-30 April 2011.

Conradie, EM 2010. Christianity and a Critique of Consumerism: A Survey of Six Points of Entry. Wellington, South Africa: Bible Media

Conradie, EM 2003. How can we help raise an environmental awareness in the South African context? Scriptura 82:122-138.

Conradie, EM 2005. HIV/Aids and Human Suffering: Where on Earth is God? Scriptura 89:406-432.

Conradie, EM 2000. Hope for the Earth: Vistas on a New Century. Cape Town: Salty Print.

Chia, R 2011. A Different Gospel: Why Prosperity teaching must be rejected. The Courier, January 2011:6-7.

Hinsdale, MA 1995."Heeding the voices”. In: O’Hara Graff, A (ed.), In the Embrace of God: Feminist Approaches to Theological Antropology. Maryknoll, New York: Orbis. 22-50.

Holmes, RL 1998. Basic Moral Philosophy, $2^{\text {nd }}$ edition. New York: Wadsworth Publishing Company.

Hooks, B 2000. Where we stand. New York: Routledge.

Huber, W 1993. "Toward an Ethic of Responsibility". Journal of Religion 73/4:573-591.

Judge, M 2009. In the garden of 'good' and 'evil': Lesbians and (in)visible sexualities in the patriarchy. A Consultation Held at Mount Fleur Conference Centre, Stellenbosch, 5 and 6 March 2009:11-18.

Kanyoro, M 2002. "Beads and Strands: Threading More Beads in the Story of the Circle". In: Phiri, IA, Govinden, DB \& Nadar, S (eds.), Her-stories: Hidden Histories of Women of Faith in Africa. Pietermaritzburg: Cluster Publications.

Kretzschmar, L 1998. “Gender, women and ethics”. In: Kretzschmar, L \& Hulley, L (eds.), Questions about Life and Morality: Christian Ethics in South Africa Today. Pretoria: JL Van Schaik.

Manda, DL 2009. "Religions and the Responsibility of Men in Relation to HIV and Gender-Based Violence: An Ethical Call". Journal of Constructive Theology, Vol. $15.2(2009: 23-40)$.

Mouton, E 2003. From woundedness towards healing: A rhetoric of pastoral-theological vision? $14^{\text {th }}$ National Conference: Southern African Association for Pastoral Work, Cape Town, 12-14 May 2003.

Nadar, S 2009. Who's Afraid of the Mighty Men's Conference? Palatable Patriarchy and Violence AgainstWo/men ${ }^{l}$ in SA. The Evil of Patriarchy in Church, Society and Politics. A Consultation Held at Mount Fleur Conference Centre, Stellenbosch, 5 and 6 March 2009:19-30.

Nagl-Docekal, H 2004. Feminist Philosophy. Oxford: Westview Press.

Pillay, M 2009a. "Women in the Church: Toward Developing Community in the context of HIV and AIDS". In: Chitando, E \& Hadebe, N (eds.), Compassionate Circles: African Women Theologians Facing HIV. Geneva: WCC. 
Pillay, M 2009b. "Through the Eyes of a Mother. Re-reading Luke's Mary as a Resource for Gender Equality in the $21^{\text {st }}$ Century?". In: Pillay, M, Nadar, S \& Le Bruyns, C (eds.), Ragbag Theologies. Essays in honour of Denise M Ackermann, a Feminist Theologian of Praxis. Stellenbosch: Sun Press.

Pillay, MN 2003a. Church Discourse on HIV/AIDS: A Responsible Response to a Disaster? Scriptura 82:108-121.

Pillay, MN 2003b. "Women and the Church. Solidarity in Suffering in the context of HIV/AIDS". In: Sporre, K and Botman, HR (eds.), Building a human rights culture: South African and Swedish perspectives. Falun: Stralins, pp. 142-163.

Pillay, MN 2006. The church on Abortion: Moving beyond the pro-life/pro-choice debate An Anglican view. Journal of Constructive Theology, Vol 12, no. 2 (2006:65-87).

Pillay, MN 2005. Luke 7:36-50: See this Women? Toward a Theology of Gender Equality in the Context of HIV and Aids. Scriptura 89:441-455.

Pillay, M in conversation with Vergnani, T, 2008. "Challenging stigma in the context of HIV/AIDS: Towards integrating individual and Societal Intervention Strategies”. In De Gruchy, S, Koopman, N and Strijbos, S (eds.), From our Side: Emerging Perspectives on Development and Ethics. Amsterdam: Rosenberg Publishers, 209-222.

Rakoczy, S 2004. In Her Name: Women Doing Theology. Pietermaritzburg: Cluster Publications.

Rakoczy, S 2009. "Ecofeminist Spirituality - of and For Life". In: Pillay MN, Nadar S and Le Bruyns C (eds.). Ragbag Theologies: Essays in Honour of Denise AckermannA Feminist Theologian of Praxis. Stellenbosch: Sun Press.

Ruether, RR 1993. Sexism and God-Talk: Toward a feminist theology. Boston: Beacon Press.

Smit, D 1997. "Liturgy and Life? On the importance of Worship for Christian Ethics". Scriptura 63:259-280.

Soelle, D 1993. On Earth as in Heaven: A Liberation Spirituality of Sharing. Louisville, Kentucky: Westminister/John Knox Press.

Sporre, K, 2009. "Post-apartheid Challenges to Theologians: A Swedish Feminist Reflection on Conditions for a Common Humanity". In: Pillay MN, Nadar S and Le Bruyns C (eds.). Ragbag Theologies: Essays in Honour of Denise AckermannA Feminist Theologian of Praxis. Stellenbosch: Sun Press.

Tutu, Desmond 2002. "Foreword”. In: Habel, NC \& Balabanski, V (eds.). The Earth Story in the New Testament, Vol. 5. Cleveland: Pilgrim Press.

Warmback, AE with Khumalo, L 2008. "The Oikos Journey: Reflections on economy, ecology and Diakonia.In De Gruchy, S, Koopman, N and Strijbos, S (eds.), From Our Side: Emerging Perspectives on Development and Ethics. Amsterdam: Rosenberg Publishers, 151-170.

Weidman, JL (ed.) 1984. "Introduction" In: Weideman, JL, Christian Feminism: Visions of a new Humanity. New York: Harper and Row.

World Council of Churches, 1997. Facing AIDS: The Challenge, The Churches' Response. A WCC Study Document. Geneva: WCC Publications.

Young, IM 1990. Justice and Politics of Difference. New Jersey: Princeton University Press, 39-65. 


\section{Other sources}

Archbishop of Cape Town, Rt Revd Ndungane. Daily News, 7 July 2005:2.

Albo, G 2008. Share the World's Resources. www.stwr.org/india-china-asia $>20$ April 2011.

Bric 2011. www.wikipedia.org/wiki/BRIC>10 April 2011.

Brics, 2011.www.afriqueavenir.org/en/2011/04/14>10 April 2011.

Conway-Smith, E 2011. "South Africa to be a BRIC". http://www.globalpost.com/dispatch/south-africa/110107/south-africa-be-bric> 20 April 2011.

Garfield, J 2010. "It's easy to create wealth". www.identitynetwork.org/apps/articles/default.asp?articleid $=70355 \&$ columned $=$ nor ef $>23$ April 2011.

Hsu, R 2011. South Africa the Next Emerging Market Powerhouse? www.investorplace.com/38307> 5 April 2011.

Kowitt, B 2009. "For Mr. BRIC, nations meeting a milestone". http://money.cnn.com/2009/06/17/news/economy/goldman_sachs_jim_oneill_interv iew.fortune/index.htm. > 19 April 2011.

Latham, D 2011. "Energy sector gets a BRICS boost". www.businessday.co.za/articles/Content>23 April 2011.

Podder, T \& Yi, E 2007. India's Rising Growth Potential. Global Economic Paper No: 152. http://www.usindiafriendship.net/viewpoints1/Indias_Rising_Growth_Potential.pdf. $>19$ April 2011.

Smith, JA 2011. "BRIC Becomes BRICS: Changes on the Geopolitical Chessboard".http://www.foreignpolicyjournal.com/2011/01/21/bric-becomes-bricschanges-on-the-geopolitical-chessboard/2/> 20 April 2011. www.crossconnections.net/mighty-men-conference-2010>5 April 2011.

The Economist 2010. China's share of world market rising. www.startribune.com/business/81176812> 15 April 2011.

Zuma to BRICS: invest in Africa's growth, 2011. SA brings 'unique attributes' to BRICS www.southafrica.info/global/brics/> 12 April 2011. 